\title{
Evaluation of the combined and separate action of the Quercus cortex extract and an antibiotic on the amino acid composition of broilers' muscle tissue
}

\author{
Galimzhan Duskaev², Olga Kvan ${ }^{1,2,}$, Shamil Rakhmatullin ${ }^{2}$, Elena Sheida ${ }^{1,2}$, and Irina Gavrish ${ }^{2}$ \\ ${ }^{1}$ Orenburg State University, 460018, 13, Pobedy prospect, Orenburg, Russia \\ ${ }^{2}$ Federal Research Center of Biological Systems and Agrotechnologies of the Russian Academy of Sciences, 29, 9 Yanvarya., Orenburg \\ 460000, Russia
}

\begin{abstract}
The industrial technology of broiler bird production broadens requirements for supplying birds with various biologically active substances. One of the most important elements of the intensive technology of producing poultry meat is organization for full and balanced feeding, which is the basis of the most complete manifestation of the productivity genetic potential, the efficient use of nutrients from the ration, the high natural resistance of the organism, and the product quality. Preventive measures in the context of modern poultry production should organically fit the process. In this aspect, the most promising technique is group prophylaxis with plant extracts or phytobiotics and traditional antibiotics capable to improve the quality of meat products. The study revealed the primary increase of the content of essential and nonessential amino acids in the pectoral muscles of the broilers that additionally received the oak bark extract as part of the ration compared to the control. The femoral muscles did not discover any clearly traced decline or increase of the content of nonessential and essential amino acids. The use of the oak bark extract without the antibiotic stimulated the accumulation of nonessential and essential amino acids mainly in the pectoral muscles of broilers, which has great economic value.
\end{abstract}

\section{Introduction}

Nowadays, the industrial technology of broiler bird production broadens requirements for supplying birds with various biologically active substances [1-3]. One of the most important elements of the intensive technology of producing eggs and poultry meat is organization for full and balanced feeding, which is the basis of the most complete manifestation of the productivity genetic potential, the efficient use of nutrients from the ration, the high natural resistance of the organism, and the product quality $[4,5]$. Preventive measures in the context of modern poultry production should organically fit the process. In this aspect, the most promising technique is group prophylaxis with plant extracts or phytobiotics, for example oak bark, and traditional antibiotics capable to improve the quality of meat products [6-8].

Poultry meat is one of the most important elements of a healthy diet. It is a source of digestible protein, fatty acids, and vitamins. Poultry meat contains more protein than any other meat while comprising a low content of fat, which provides a full balance of protein in the body.

The search for and the practical application of new techniques to improve the quality of poultry meat and to increase contents of nonessential and essential amino acids in it look promising.

\section{Materials and Methods}

Experimental studies were carried out at the Center for collective use of scientific equipment of the Federal State Scientific Institution "Federal Research Center of Biological Systems and Agro-technologies of the Russian Academy of Sciences" (FSSI FRC BST RAS), the experiments were held in vivo (Gallus gallus). 120 heads of 7-day-old broiler chickens were selected for experiments ("Smena-8", four groups, $\mathrm{n}=30$ ). The control group received the main ration (MR), experimental group I - MR + the extract from Quercus cortex; experimental group II - MR + an antibiotic based on $20 \%$ chlortetracycline (dosed in accordance with recommendations of the manufacturer); experimental group III - MR + the antibiotic + the extract from Quercus cortex.

Bird treating and experimental procedures met the requirements and recommendations of Russian rules (order of the Ministry of the health of the USSR № 755 of 12.08.1977) and "The Guide for the Care and Use of Laboratory Animals" (National Academy Press Washington, D.C. 1996). Watering was not regulated.

Before the slaughter, the birds were kept on a starvation diet (except drinking) for 12 hours. Observed after the slaughter pectoral and femoral muscles of

\footnotetext{
*E-mail: kwan111@yandex.ru, Tel: +7 (922) 548-56-57.
} 
chicken broilers were the material for our study. Organoleptic studies were conducted in accordance with GOST 51944-2002 "Poultry meat. Methods for determination of organoleptic properties, temperature, and mass" paying attention to superficies, smell, the state of the muscles in section, the status of fat, transparency and the flavor of the broth.

The content of nonessential and essential amino acids was measured by the method of capillary electrophoresis (the capillary electrophoresis system "Kapel-105 M", Lumex). Their ratio served to evaluate the protein qualitative index (PQI).

Statistical processing of the data was carried out using the Statistica 10.0 software package. Data are presented as: mean $(\mathrm{M}) \pm$ standard error of the mean $(\mathrm{m})$. Significant results were considered at $\mathrm{P} \leq 0.05$.

\section{Results and Discussion}

The organoleptic studies of the pectoral and femoral muscles of chicken broilers of experimental and control groups showed that all samples had dry surfaces; the subcutaneous and internal adipose tissues were strawcolored, without pathological formations. The tissue of the pectoral muscle was white in section, the surface of the sectional cut was slightly moist, the meat juice was transparent; the femoral muscle was of pale pink color, the consistency of the samples was dense and elastic. The smell on the surface and in section was peculiar, typical for fresh poultry meat. When boiling meat, the broth was transparent with no flakes, foreign smells were absent.

Poultry meat is the most full value and dietary product in comparison with meat of other agricultural animals as poultry meat contains more full value and less hard digestible proteins (collagen and elastin), which makes its high nutritional value. The nutritional value of meat is determined by its amino acid composition.

The studies on the amino acid composition of the pectoral and femoral muscles in chicken broilers of the experimental and control groups revealed 13 amino acids, 6 of which are essential and directly affect the value of muscle protein (Tables 1 to 4 ).

Among essential amino acids in the pectoral muscle of broiler-chickens, we found the following amino acids: lysine, phenylalanine, methionine, valine, and threonine. Accounting the fact that the isoleucine deficiency gets compensated by leucine, the amino acids were combined together in leucine-isoleucine (table 1).

Table 1. Content of essential amino acids in the pectoral muscles of broiler chickens, $\%$

\begin{tabular}{lcccc}
\hline $\begin{array}{c}\text { Content of amino } \\
\text { acid, } \%\end{array}$ & Control & $\begin{array}{c}\text { I } \\
\text { experimental }\end{array}$ & $\begin{array}{c}\text { Groups } \\
\text { experimental }\end{array}$ & $\begin{array}{c}\text { III } \\
\text { experimental }\end{array}$ \\
\hline $\begin{array}{l}\text { Lysine } \\
\text { Phenylalanine }\end{array}$ & $9.37 \pm 0.26$ & $12.9 \pm 0.22^{* *}$ & $10.3 \pm 0.22$ & $11.0 \pm 0.25^{*}$ \\
Leucine- & $3.78 \pm 0.18$ & $4.72 \pm 0.24^{*}$ & $3.84 \pm 0.30$ & $4.01 \pm 0.25$ \\
isoleucine & $11.7 \pm 0.28$ & $15.7 \pm 0.20^{*}$ & $12.6 \pm 0.16$ & $13.5 \pm 0.24^{*}$ \\
Methionine & & & & $2.45 \pm 0.21$ \\
Valine & $2.81 \pm 0.24$ & $4.44 \pm 0.28^{*}$ & $2.30 \pm 0.17$ & $4.43 \pm 0.20$ \\
Threonine & $3.86 \pm 0.27$ & $5.41 \pm 0.28^{*}$ & $4.10 \pm 0.27$ & $4.69 \pm 0.77$ \\
\hline
\end{tabular}

$*-\mathrm{p} \leq 0.05 ; * *-\mathrm{p} \leq 0.01-$ significant differences to the control group

Studies on the content of essential amino acids showed a significant increase for all essential amino acids in the first experimental group that additionally received the oak bark extract in comparison with the control: lysine - by $27.4 \%(\mathrm{p} \leq 0.01)$ phenylalanine - by $27.1 \%(\mathrm{p} \leq 0.05)$, leucine-isoleucine - by $25.5 \%(\mathrm{p} \leq$ $0.05)$, methionine - by $36.7 \%$ ( $\mathrm{p} \leq 0.05)$, valine - by $28.7 \%(p \leq 0.05)$, and threonine - by $27.9 \%(p \leq 0.05)$.

In the second experimental group, we observed a similar pattern of increasing the content of essential amino acids but changes were not significant. The third experimental group that additionally received the oak bark extract and an antibiotic - chlortetracycline, which, in our case, resulted in a significant increase of lysine by $14.8 \%$ and leucine-isoleucine by $13.3 \%$ ( $p \leq 0.05)$ compared to the control group.

The analysis of the content of nonessential amino acids in the pectoral muscles of the studied birds gave us a similar picture as essential amino acids in the first experimental group did, namely - a significant increase
( $\mathrm{p} \leq 0.05$ ) of all nonessential amino acids: arginine - by $24.4 \%$, tyrosine - by $27.1 \%$, histidine - by $27.6 \%$, proline - by $25.9 \%$, serine - by $32.1 \%$, alanine - by $28.7 \%$, and glycine - by $28.1 \%$ compared to the control group (table 2).

The analysis of the amino acid composition in femoral muscles of broilers of the experimental groups found some different changes in the amino acid contents. So, we observed a significant decline of arginine by 1.6 times $(\mathrm{p} \leq 0.05)$ in the first experimental group in comparison with the control group. Regarding other nonessential amino acids, there also were declines in comparison with the control: tyrosine - by $8.3 \%$, histidine - by $12.4 \%$, proline - by $17.9 \%$, proline - by $19.2 \%$, serine - by $19.2 \%$, alanine - by $17.9 \%$, and glycine - by $15.5 \%$, however, it should be noted, all changes were not significant (table 3 ).

The second experimental group showed a similar pattern of declining levels of nonessential amino acids, and the changes were not of a significant character as 
well. In the third experimental group, the picture was the opposite, namely we recorded increases of such amino acids as arginine, tyrosine, proline, alanine, and glycine by $3.02 \%, 1.95 \%, 6.06 \%, 6.78 \%$, and $1.18 \%$ respectively compared to the control group, but there were not observed significant changes.

Table 2. Content of nonessential amino acids in the pectoral muscles of broiler chickens, $\%$

\begin{tabular}{lcccc}
\hline $\begin{array}{c}\text { Content of amino } \\
\text { acid, } \%\end{array}$ & Control & $\begin{array}{c}\text { I } \\
\text { experimental }\end{array}$ & $\begin{array}{c}\text { II } \\
\text { experimental }\end{array}$ & $\begin{array}{c}\text { III } \\
\text { experimental }\end{array}$ \\
\hline Arginine & $5.60 \pm 0.21$ & $7.41 \pm 0.57^{*}$ & $6.72 \pm 0.44$ & $7.18 \pm 0.27^{*}$ \\
Tyrosine & $4.5 \pm 0.24$ & $6.17 \pm 0.15^{*}$ & $5.8 \pm 0.26$ & $5.78 \pm 0.26$ \\
Histidine & $2.67 \pm 0.21$ & $3.68 \pm 0.16^{*}$ & $2.98 \pm 0.27$ & $2.9 \pm 0.3$ \\
Proline & $2.78 \pm 0.23$ & $3.75 \pm 0.17^{*}$ & $3.12 \pm 0.19$ & $3.19 \pm 0.24$ \\
Serine & $3.56 \pm 0.27$ & $5.24 \pm 0.24^{*}$ & $4.02 \pm 0.26$ & $4.07 \pm 0.2$ \\
Alanine & $6.9 \pm 0.29$ & $9.68 \pm 0.27^{*}$ & $7.86 \pm 0.15^{*}$ & $8.10 \pm 0.26^{*}$ \\
Glycine & $4.10 \pm 0.18$ & $5.70 \pm 0.22^{*}$ & $4.67 \pm 0.21$ & $4.75 \pm 0.23$ \\
\hline
\end{tabular}

Table 3. Content of nonessential amino acids in the femoral muscles of broiler chickens, $\%$

\begin{tabular}{lcccc}
\hline $\begin{array}{c}\text { Content of amino } \\
\text { acid, } \%\end{array}$ & Control & $\begin{array}{c}\text { I } \\
\text { experimental }\end{array}$ & $\begin{array}{c}\text { II } \\
\text { experimental }\end{array}$ & $\begin{array}{c}\text { III } \\
\text { experimental }\end{array}$ \\
\hline Arginine & $5.78 \pm 0.22$ & $3.65 \pm 0.18^{* *}$ & $4.43 \pm 0.24$ & $5.96 \pm 0.28$ \\
Tyrosine & $3.02 \pm 0.25$ & $2.77 \pm 0.25$ & $2.69 \pm 0.21$ & $3.08 \pm 0.28$ \\
Histidine & $2.10 \pm 0.20$ & $1.84 \pm 0.16$ & $2.05 \pm 0.27$ & $2.03 \pm 0.22$ \\
Proline & $2.79 \pm 0.24$ & $2.29 \pm 0.14$ & $2.53 \pm 0.26$ & $2.97 \pm 0.22$ \\
Serine & $3.55 \pm 0.23$ & $2.87 \pm 0.22$ & $3.19 \pm 0.23$ & $3.5 \pm 0.26$ \\
Alanine & $5.91 \pm 0.23$ & $4.85 \pm 0.24$ & $5.38 \pm 0.24$ & $6.34 \pm 0.28$ \\
Glycine & $4.19 \pm 0.27$ & $3.54 \pm 0.20$ & $3.83 \pm 0.21$ & $4.24 \pm 0.26$ \\
\hline
\end{tabular}

Table 4. Content of essential amino acids in the femoral muscles of broiler chickens, $\%$

\begin{tabular}{lcccc}
\hline $\begin{array}{c}\text { Content of amino } \\
\text { acid, } \%\end{array}$ & Control & $\begin{array}{c}\text { I } \\
\text { experimental }\end{array}$ & $\begin{array}{c}\text { Groups } \\
\text { experimental }\end{array}$ & $\begin{array}{c}\text { III } \\
\text { experimental }\end{array}$ \\
\hline Lysine & $8.81 \pm 0.24$ & $6.97 \pm 0.20^{*}$ & $7.84 \pm 0.23$ & $9.41 \pm 0.27$ \\
Phenylalanine & $3.16 \pm 0.18$ & $2.58 \pm 0.16$ & $2.82 \pm 0.23$ & $3.33 \pm 0.26$ \\
$\begin{array}{l}\text { Leucine- } \\
\text { isoleucine }\end{array}$ & $10.9 \pm 0.25$ & $8.69 \pm 0.21^{*}$ & $9.80 \pm 0.23$ & $11.2 \pm 0.29$ \\
Methionine & $2.05 \pm 0.22$ & $2.37 \pm 0.21$ & $3.71 \pm 0.29 *$ & $1.90 \pm 0.24$ \\
Valine & $3.26 \pm 0.21$ & $2.60 \pm 0.19$ & $3.00 \pm 0.23$ & $3.45 \pm 0.27$ \\
Threonine & $3.96 \pm 0.26$ & $3.11 \pm 0.20$ & $3.52 \pm 0.22$ & $4.06 \pm 0.30$ \\
\hline
\end{tabular}

$* *-\mathrm{p} \leq 0.01$

Speaking of essential amino acids in the femoral muscles, we recorded a significant decline of lysine by $20.9 \%$ and leucine-isoleucine by $20.3 \%(p \leq 0.05)$ in the first experimental group compared to the control, all changes in the remaining experimental groups were not of a significant nature (table 4).

The ratio of the number of essential amino acids to nonessential ones in the pectoral muscles of broiler chickens in the first experimental group amounted to 1.18 , in group $2-1.07$, and in group $3-1.11$. The femoral muscles showed the following ratio: for the first experimental group -1.21 , for group $2-1.27$, for group $3-1.19$, the control groups had this ratio amounted to 1.19 and 1.18 for the pectoral and femoral muscles, respectively. For the amino acid composition, it indicates positive changes that increase the biological value of the meat, because the amount of essential amino acids increases and the number of nonessential ones decreases.

The study revealed the primary increase of the content of essential and nonessential amino acids in the pectoral muscles of the broilers additionally receiving the oak bark extract as part of the ration compared to the control. The femoral muscles did not discover any clearly traced decline or increase of the content of nonessential and essential amino acids. Thus, the use of the oak bark extract without the antibiotic stimulated the accumulation of nonessential and essential amino acids 
mainly in the pectoral muscles of broilers, which has great economic value.

As it is known, phytobiotics are natural stimulants of growth and may become a promising substitute for antibiotic growth stimulants in the modern animal husbandry [6]. Also, the overall impact of phytobiotics on agricultural animals and birds is associated not only with the antimicrobial effect but also with their positive effects on digestion. Phytobiotics stimulate the production of endogenous enzymes improving digestibility and assimilation of nutrients. Many of them serve as natural flavors that stimulate feed intake, which has a positive effect on the productivity of animals [9$10]$.

\section{Conclusions}

1. The main reasons why phytogenic feed additives are used in animal husbandry are the improvement of feed digestibility, the stimulation of growth, leverage of the feed conversion ratio and increased feed intake by animals.

2. It should be noted that the combined use of the oak bark extract with the antibiotic chlortetracycline is promising in its application with traditional grain products (wheat, rice, corn, oats, barley, etc.), which are deficient in essential amino acids, primarily in lysine.

It will help receive a nutritious product optimally balanced on the contents of essential amino acids.

\section{Acknowledgement}

The research was conducted with financial support from the Russian Science Foundation (Grant \#16-16-10048).

\section{References}

1. M. Petracci, S. Mudalal, F. Soglia, C. Cavani, World's Poultry Science Journal 71, 363-374 (2015)

2. V.A. Bagirov, G.K. Duskaev, N.M. Kazachkova, Sh.G. Rakhmatullin, E.V. Yausheva, D.B. Kosyan, Sh.A. Makaev, Kh.B. Dusaeva, Sel'skokhozyaistvennaya Biologiya 53(4), 799-810 (2018)

3. E. Sizova, S. Miroshnikov, S. Lebedev, Y. Levakhin, I. Babicheva, V. Kosilov, Sel'skokhozyaistvennaya Biologiya 53, 393-403 (2018)

4. A. Trocino, A. Piccirillo, M. Birolo, G. Radaelli, D. Bertotto, E. Filiou, G. Xiccato, Poultry Science 94, 2996-3004 (2015)

5. N. Mir, A. Rafiq, F. Kumar, V. Singh, V. Shukla, Journal of food science and technology 54, 29973009 (2017)

6. H. Alakomi, J. Maukonen, K. Honkapää, E. Storgårds, K. Quirin, B. Yang, M. Saarela, Journal of food protection 80, 1689-1696 (2017)

7. G. Duskaev, N. Kazachkova, A. Ushakov, B. Nurzhanov, A. Rysaev, Veterinary World 11, 235 239 (2018)
8. V.I. Fisinin, A.S. Ushakov, G.K. Duskaev, N.M. Kazachkova, B.S. Nurzhanov, Sh.G. Rakhmatullin, G.I. Levakhin, Sel'skokhozyaistvennaya Biologiya 53(2), 385-392 (2018)

9. F. Alipour, A. Hassanabadi, A. Golian, H. NassiriMoghaddam, Poultry science 94(11), 2630-2634 (2015)

10. P.C. Devi, A.K. Samanta, B. Das, G. Kalita, P.S. Behera, S. Barman, Indian Journal of Animal Nutrition 35(4), 421-427 (2018) 